\title{
ANALISA PEMBIAYAAN PROPERTI MENGGUNAKAN AKAD MURABAHAH
}

(Studi Kasus Pada Bank Muamalat Indonesia)

\author{
Edwin Rahmat Yulianto, ME \\ Dosen Fakultas Agama Islam As Syafiiyah Jakarta \\ edwynrahmat@gmail.com
}

\begin{abstract}
ABSTRAK - Penelitian ini bertujuan untuk mengetahui bagaimana aplikasi akad Murabahah pada Bank Muamalat Indonesia. Penelitian ini bersifat kualitatif berbasis deskriptif dengan melakukan studi lapangan. Penelitian ini menggunakan analisis SWOT, yaitu dengan menganalisa faktor internal yaitu kekuatan, kelemahan, serta menganalisa faktor eksternal yaitu peluang maupun ancaman dari akad tersebut. Hasil dari penelitian ini adalah akad Murabahah berada dalam posisi yang kuat dan berpeluang terus meningkat, sehingga bisa menghasilkan profit pada Bank Muamalat Indonesia.
\end{abstract}

ABSTRACT - This study aims to determine how the application of the Murabahah contract at Bank Muamalat Indonesia. This research is a descriptive qualitative based by conducting field reaserch. This study uses a SWOT analysis, namely by analyzing internal factors, namely strengths, weaknesses, and analyzing external factors, the opportunities and threats of the contract. The results of this study are the Murabahah contract is in a strong position and has the opportunity to continue to increase, so that it can generate profits at Bank Muamalat Indonesia.

\section{PENDAHULUAN}

Berbicara tentang properti, pasti tidak lepas dari berbicara tentang kebutuhan masyarakat pada umumnya. Properti terutama rumah merupakan kebutuhan primer setiap masyarakat, terutama masyarakat yang tinggal di didaerah perkotaan. Dengan keadaan lahan yang sangat terbatas yang menyebabkan semakin tingginya harga jual dari tahun ke tahun di sektor properti terutama properti residensial. Keterbatasan lahan adalah salah satu 
faktor yang membuat House Price Index (HPI) menjadi meningkat seiring dengan meningkatnya pertumbuhan penduduk. Dengan meningkatnya prospek bisnis properti tentu saja peran perbankan menjadi sangat penting dalam segi pembiayaan. Menurut data Bank Indonesia, pembelian rumah konsumen di Indonesia sebagian besar masih menggunakan Kredit Pembiayaan Rumah (KPR). Dengan adanya KPR maka solusi untuk memiliki rumah bisa dengan mudah terwujud. Hal tersebut di buktikan pada Triwulan IV-2018, presentase konsumen melakukan pembelian rumah dengan menggunakan KPR sebanyak 76,73\%, lebih rendah dari triwulan sebelumnya sebesar $77,20 \%$. Sedangkan konsumen yang membeli rumah dengan tunai bertahap meningkat dari $15,12 \%$ menjadi $15,86 \%$.

Begitu pula dengan kredit berbasis syariah, menurut Housing Finance Information terlihat dari nilai total kredit syariah bulan Februari 2019 sebesar Rp320,98 triliun, mampu tumbuh 13,79\% (yoy) dibandingkan total kredit syariah pada bulan Februari 2018 sebesar Rp282,10 triliun.
Pertumbuhan total kredit syariah tersebut sejalan dengan meningkatnya nilai outstanding KPR syariah. Pada bulan Februari 2019, nilai outstanding KPR syariah mencapai $\mathrm{Rp} 72,30$ triliun atau meningkat 18,28\% (yoy) dibandingkan outstanding KPR syariah bulan Februari 2018 sebesar Rp61,13 trilun. Pertumbuhan KPR syariah tersebut lebih tinggi dibandingkan pertumbuhan KPR nasional sebesar $13,71 \%$ (yoy) pada bulan yang sama.

Seiring dengan meningkatnya pertumbuhan KPR Syariah mengharuskan Bank Syariah menciptakan pembiayaan yang kompetitif, maka DSN MUI mengeluarkan akad yaitu Murabahah akad tersebut yang kemudian juga digunakan pada KPR iB Muamalat Kongsi dari Bank Muamalat Indonesia (BMI). Berdasarkan permasalahan diatas maka peneliti memandang penting untuk melakukan penelitian lebih lanjut tentang bagaimana aplikasi akad Murabahah pada pembiayaan KPR iB Muamalat. 


\section{LANDASAN TEORI}

Akad Murabahah

\section{a. Konsep Jual Beli Murabahah}

Secara bahasa, murabahah berasal dari kata ribh yang bermakna tumbuh dan berkembang dalam perniagaan. Dalam istilah syariah, konsep murabahah terdapat berbagai formulasi definisi yang berbeda-beda menurut pendapat para ulama. Di antaranya, menurut Utsmani (2002: 125), murabahah merupakan salah satu bentuk jual beli yang mengharuskan penjual memberikan informasi kepada pembeli tentang biaya-biaya yang dikeluarkan untuk mendapatkan komoditas (harga pokok pembelian) dan tambahan profit yang diinginkan yang tercermin dalam harga jual.

Pendapat lain dikemukakan oleh AlKasani (tt:226-228), murabahah mencerminkan transaksi jual beli: harga jual merupakan akumulasi dari biayabiaya yang telah dikeluarkan untuk mendatangkan objek transaksi atau harga pokok pembelian dengan tambahan keuntungan tertentu yang diinginkan penjual (margin). Harga jual beli dan jumlah keuntungan yang diinginkan diketahui oleh pembeli. Artinya, pembeli diberitahu berapa harga belinya dan tambahan keuntungan yang diinginkan.

Murabahah menekankan adanya pembelian komoditas berdasarkan permintaan konsumen dan proses penjualan kepada konsumen, dengan harga jual yang merupakan akumulasi dari biaya beli dan tambahan profit yang diinginkan. Dengan demikian bila terkait dengan pihak bank diwajibkan untuk menerangkan tentang harga beli dan tambahan keuntungan yang diinginkan kepada nasabah. Dalam konteks ini bank tidak meminjamkan uang kepada nasabah untuk membeli komoditas tertentu tetapi pihak banklah yang berkewajiban kepada nasabah dengan harga yang disepakati kedua belah pihak

Murabahah berbeda dengan jual beli biasa (musawamah). Dalam jual beli Musawamah terdapat proses tawarmenawar (bargaining) antara penjual dan pembali untuk menentukan harga jual penjual juga tidak menyebutkan harga beli dan keuntungan yang diinginkan, berbeda dengan murabahah, harga beli dan margin yang diinginkan harus dijelaskan kepada pembeli. 


\section{b. Syarat dan Rukun Jual Beli Murabahah}

Dalam Jual beli Murabahah, Al-Kasani (tt:220-222) menyatakan bahwa akad bai' murabahah akan dikatakan sah jika memenuhi beberapa syarat berikut ini :

1. Mengetahui harga pokok (harga beli). Disyaratkan bahwa harga beli harus diketahui oleh pembeli kedua, karena hal itu merupakan syarat mutlak bagi keabsahan bai' murabahah penjual kedua harus menerangkan harga beli kepada pihak pembeli kedua hal ini juga berlaku bagi jual beli yang berdasarkan kepercayaan seperti halnya at-tauliyah, al-isyrak ataupun al-wadhah Akad jual beli ini berdasarkan pada kejelasan informasi tentang harga beli, jika harga beli tidak dijelaskan kepada pembeli kedua dan ia telah meninggalkan majlis, maka jual beli dinyatakan akadnya batal.

2. Adanya kejelasan keuntungan (margin) yang diinginkan penjual kedua, keuntungan harus dijelaskan nominalnya, kepada pembeli kedua atau dengan menyebutkan persentase dari harga beli, margin juga merupakan bagian dari harga, karena harga pokok plus margin merupakan harga jual dan mengetahui harga jual merupakan syarat sahnya jual beli.

3. Modal yang digunakan untuk membeli objek transaksi harus merupakan barang mitsli, dalam arti terdapat padanannya dipasaran, alangkah baiknya jika menggunakan uang modal yang dipakai merupakan barang qimi/ghair mitsli, misalnya pakaian dan margin nya berupa uang maka diperbolehkan. Misalnya saya jual sepeda motor Yamaha ini dengan sepeda motor Honda yang kami miliki ditambah dengan Rp1.000.000,- sebagai margin. bila akadnya demikian maka diperbolehkan

4. Objek transaksi dan alat pembayaran yang digunakan tidak boleh berupa barang ribawi seperti halnya menjual 100 dollar dengan harga 110 dollar, margin yang diinginkan (dalam hal ini 10 dollar) bukan merupakan keuntungan yang diperbolehkan akan tetapi merupakan bagian dari riba.

5. Akad jual beli pertama harus sah adanya artinya transaksi yang dilakukan penjual pertama dan pembeli pertama harus sah, jika tidak transaksi yang dilakukan penjual 
kedua (pembeli pertama) dengan pembelian kedua hukumannya fasid/rusak dan kadanya batal.

6. Bai' Murabahah merupakan jual beli yang disandarkan pada sebuah kepercayaan karena pembeli percaya atas informasi yang diberikan penjual tentang harga beli yang diinginkan, dengan demikian penjual tidak boleh berkhianat.

Menurut jumhur ulama, rukun dan syarat yang terdapat dalam bai' murabahah sama dengan rukun dan syarat yang terdapat dalam jual beli dan hal itu identik dengan rukun dan syarat yang harus ada dalam akad, menuurt Hanafiyah rukun yang terdapat dalam jual beli hanya satu, yaitu sighah (ijab dan qabul) adapun rukun-rukun lainnya merupakan derivasi dari sighah, artinya sighah tidak akan ada jika tidak terdapat dua pihak yang bertransaksi misalnya, penjual dan pembeli dalam melakukan akad (sighah) tentunya ada sesuatu yang harus ditransaksikan, yakni objek transaksi.

Ijab dan Qabul merupakan representasi dari sighah ia merupakan uangkapan yang dikeluarkan oleh kedua pihak yang bertransaksi untuk mengungkapkan keinginan masing- masing guna mewujudkan atau membangun sebauh kesepakatan/kontrak, hal itu bisa dilakukan secara verbal dengan katakata dengan tindakan-tindakan tertentu dengan isyarat, lewat surat, e-mail, fax atau via telepon.

Dalam ijab dan qabul terdapat beberapa syarat yang harus dipenuhi, menurut Az-Zuhaily (1989: 105-106) sebagai berikut :

1. Adanya kejelasan maksud dari kedua pihak, dalam arti ijab dan qabul yang dilakukan harus bisa mengekpresikan tujuan dan maksud keduanya dalam bertransaksi. Penjual mempu memahami apa yang diinginkan oleh pembeli dan begitu sebaliknya.

2. Adanya kesesuaian antara ijab dan qabul, terdapat kesesuaian antara ijab dan qabul dalam hal objek transaksi ataupun harga artinya terdapat kesamaan diantara keduanya, tentang kesepakatan maksud dan objek transaksi, Jika tidak terdapat kesesuaian maka akad dinyatakan batal.

3. Adanya pertemuan antara ijab dan qabul (berurutan dan bersambung), yakni ijab dan qabul dilakukan 
dalam satu majlis. Satu majlis di sini tidak berarti harus bertemu secara fisik dalam satu tempat, yang terpenting adalah kedua pihak mampu mendengarkan maksud dari kedua pihak, apakah akan menetapkan kesepakatan atau menolaknya, Majlis akad bisa diartikan sebagai sesuatu kondisi yang memungkinkan kedua pihak untuk membuat kesepakatan atau pertemuan pembicaraan dalam satu objek transaksi dalam hal ini diisyaratkan adanya kesepakatan antara kedua pihak tidak menunjukkan adanya penolakan atau pembatalan dari keduanya.

Menurut Az-Zuhaily (1989: 114) Ijab dan Qabul akan dinyatakan batal jika :
a. Penjual menarik kembali ungkapannya sebelum terdapat qabul dari pembeli

b. Adanya penolakan ijab oleh pembeli dalam arti apa yang diungkapkan penjual tidak disetujui/ditolak oleh pembeli.

c. Berakhirnya majlis akad jika kedua pihak belum mendapat kesepakatan dalam majlis akan dan keduanya telah terpisah maka ijab qabul dinyatakan batal

d. kedua pihak atau salah satu pihak hilang ahliyah-nya (syarat kecakapan melakukan transaksi) sebelum terjadi kesepakatan; dan

e. rusaknya objek transaksi sebelum terjadinya qabul atau kesepakatan.

Pihak-pihak yang akan melakukan transaksi (aqid) dalam hal jual beli adalah penjual dan pembeli. Ulama Fikih memberikan persyaratan atau kriteria yang harus dipenuhi oleh aqid yakni ia harus memiliki ahliyah dan wilayah. Menurut Az-Zuhaily (1989: 117) ahliyah bermakna bahwa keduanya memiliki kepatutan atau kecakapan untuk melakukan transaksi dan mendapat otoritas syara. Biasanya mereka akan memiliki ahliyah jika telah balig dan berakal, sementara wilayah diartikan sebagai hak atau kewenangan seseorang yang mendapat legalitas syara' untuk melakukan transaksi atau suatu objek tertentu. Artinya orang tersebut memang merupakan pemilik sah, wali atau wakil atas suatu objek transaksi sehingga ia memiliki hak dan otoritas untuk mentransaksikannya. 
Objek transaksi (maqud 'alaih) yaitu sesuatu yang menjadi objek transaksi dilakukan sehingga menimbulkan implikasi hukum tertentu maqud 'alaih, bisa berupa aset-aset finansial ataupun nonfinansial seperti wanita dalam akad penikahan ataupun bisa berupa manfaat seperti halnya dalam akad sewa (ijarah)

Maqud 'alaih harus memenuhi beberapa persyaratan, menurut AzZuhaily (1989: 173-181), intinya sebagai berikut :

1. Objek transaksi tersebut harus ada ketika akad/kontrak sedang dilakukan tidak diperbolehkan bertransaksi atas objek yang belum jelas dan tidak hadir dalam waktu akad karena hal itu akan menjadi masalah ketika harus dilakukan serah terima.

2. Objek transaksi tersebut harus berupa mal mutaqawwim (harta yang diperbolehkan syara' untuk ditransaksikan) dan dimiliki penuh oleh pemiliknya. Tidak boleh mentransaksikan bangkai, darah babi, anjing, minuman keras dan lain-lain begitu juga barang yang belum berada dalam genggaman pemilik, seperti ikan yang masih berada di dasar lautam burung diangkasa, dan lain-lain.

3. Objek transaksi bisa diserahterimakan waktu terjadinya akad atau dikemudian hari objek harus bisa diserahterimakan jika tidak walaupun barang tersebut ada dan dimiliki oleh aqid maka transaksi dinyatakan batal.

4. Adanya kejelasan tentang objek transaksi dalam arti barang tersebut diketahui dengan sejelas-jelasnya oleh kedua pihak hal ini dimaksudkan untuk menghindari terjadinya perselisihan di kemudian hari, objek transaksi tidak boleh bersifat majhul (tidak diketahui) dang mengandung unsur gharar.

5. Objek tersebut harus suci tidak najis dan bukan barang njis syarat ini diajukan oleh ulama selain Hanafiyah.

\section{c. Modal dan Unsur Pendukung Murabahah}

Az-Zuhaily (1989: 706-708), memberikan pembahasan bahwa modal diartikan sebagai biaya yang dikeluarkan penjual untuk mendapatkan komoditas yang dijadikan sebagai objek akad jual beli murabahah. Biaya yang digunakan untuk membeli komoditas. Modal dalam 
jual beli ini tidak hanya terdiri atas harga pokok pembelian tapi terdapat unsur pendukung lainnya yang dikeluarkan untuk mendapatkan komoditas tersebut, mulai dari biaya transportasi, administrasi, biaya pemeliharaan, biaya distribusi dan biaya lainnya yang terkait dan melekat dengan komoditas (overhead cost).

Biaya yang dikeluarkan terkait dengan kepentingan pribadi penjual tidak bisa dimasukkan dalam modal seperti makan, minum, biaya dokter dan lainnya, total dari harga pokok pembelian dan biaya-biaya pendukung ditambah dengan margin merupakan harga jual murabahah yang ditawarkan kepada pembeli.

Penjual berkewajiban untuk menerangkan semua informasi terkait dengan jual beli murabahah baik dari harga pokok pembelian maupun margin yang diinginkan. Jika dalam objek transaksi terdapat cacat maka penjual harus menjelaskannya sehingga tidak dianggap berkhianat.

Penjual juga harus menjelaskan jika ia membeli objek akad secara tempo, karena hal ini akan berpengaruh terhadap harga jual kepada pembeli jika terdapat indikasi bahwa penjual berkhianat maka pembeli memiliki hak, khiyar meneruskan atau membatalkan kompensasi ekonomis dari tindakan khianat tersebut.

\section{Akad Pembiayaan Menggunakan Skema Murabahah}

\section{a. Definisi Murabahah}

Himpunan Datwa DSN MUI,

edisi revisi 2006 menjelaskan

Murabahah adalah menjual suatu barang dengan menegaskan harga belinya kepada pembeli dan pembeli membayarnya dengan harga yang lebih tinggi sebagai laba.

Menurut PBI (Peraturan Bank Indonesia) Murabahah adalah jual beli barang sebesar harga pokok barang ditambah dengan margin keuntungan yang disepakati. (PBI No. 7/46/PBI/2005. PBI ini telah dicabut dg PBI No. 9/19/PBI/2007). Murabahah adalah transaksi jual beli suatu barang sebesar harga perolehan barang ditambah dengan margin keuntungan yang disepakati olah para pihak, dimana penjual menginformasikan terlebih dahulu harga perolehan kepada pembeli. (PBI No. 9/19/PBI/2007).

Definisi UU (Undang-Undang) akad murabahah adalah Akad 
Pembiayaan suatu barang dengan menegaskan harga belinya kepada pembeli dan pembeli membayarnya dengan harga yang lebih sebagai keuntungan yang disepakati (Penjelasan Pasal 19 Undang-Undang No. 21 tahun 2008 tentang Perbankan Syariah).

Pembiayaan Pemilikian Rumah (PPR) syariah dengan menggunakan akad murabahah adalah pertama, developer perumahan menjual rumah kepada pihak bank syariah secara tunai. Pihak developer dan bank syariah melakukan kesepakatan harga yang telah ditetapkan oleh kedua belah pihak. Setelah kesepakatan harga dicapai oleh kedua belah pihak, bank syariah membeli secara tunai. Bank syariah menjual rumah sebesar harga pokok/asal ditambah keuntungan yang disepakati bersama, kepada nasabah PPR syariah secara tangguh/angsuran. Setelah kesepakatan dicapai oleh kedua belah pihak, nasabah membeli rumah kepada bank syariah secara angsuran (Haris, 2007: 45). Berikut skema pembiayaan Pemilikan Rumah (PPR) dengan akad Murabahah :

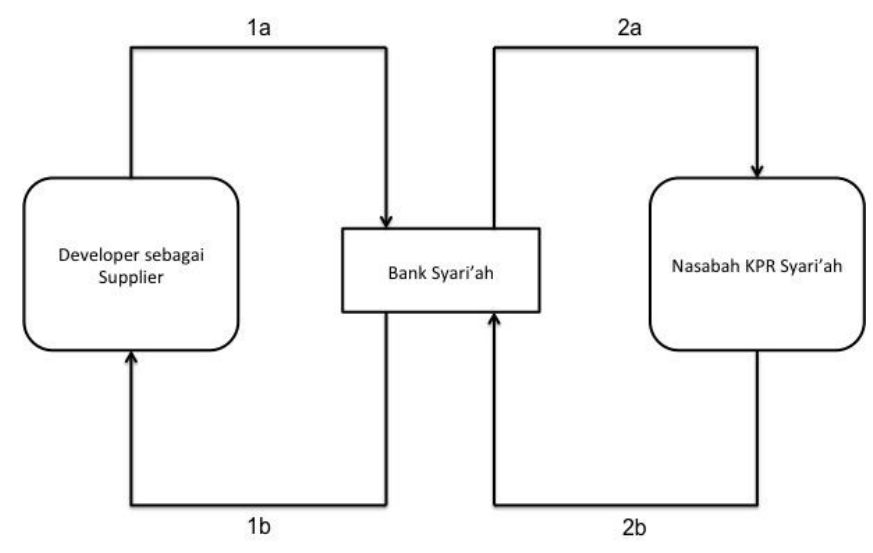

Sumber: Haris (2007: 117)

Keterangan :

1a : Developer perumahan menjual rumah kepada pihak bank syariah secara tunai 1b : Bank syariah membeli kepada developer selaku supplier secara tunai

2a : Bank syariah menjual rumah sebesar harga pokok tambah keuntungan yang disepakati bersama, kepada nasabah KPR syariah secara tangguh/angsuran 2b : Nasabah membeli kepada bank syariah secara angsuran 
b. Syarat dan Ketentuan Akad Murabahah

Rukun Bai

(Jual-Beli)

\section{Murabahah:}

1. Penjual $\left(b a^{\prime} i\right)$, yaitu pihak yang memiliki barang untuk dijual atau pihak yang ingin menjual barangnya. Dalam transaksi pembiayaan murabahah di perbankan syariah merupakan pihak penjual.

2. Pembeli (musytari) yaitu pihak yang membutuhkan dan ingin membeli barang dari penjual, dalam pembiayaan murabahah nasabah merupakan pihak pembeli.

3. Barang/objek (mabi') yaitu barang yang diperjual belikan. Barang tersebut harus sudah dimiliki oleh penjual sebelum dijual kepada pembeli, atau penjual menyanggupi untuk mengadakan barang yang diinginkan pembeli.

4. Harga (tsaman). Harga yang disepakati harus jelas jumlahnya dan jika dibayar secara hutang maka harus jelas waktu pembayaranya.
5. Ijab qabul (sighat) sebagai indikator saling ridha antara kedua pihak (penjual dan pembeli) untuk melakukan transaksi.

Dengan mengacu pada skema murabahah, dapat disimpulkan Syarat Bai' (Jual-Beli) Murabahah yang harus dipenuhi dalam transaksi PPR syariah yang sudah ditetapkan oleh Majelis Ulama Indonesia (MUI):

1. Bank syariah dan asabah harus melakukan akad murabahah yang bebas riba.

2. Barang yang diperjualbelikan tidak diharamkan oleh syariat Islam.

3. Bank syariah membiayai sebagian atau seluruh harga pembelian barang yang telah disepakati kualifikasinya.

4. Bank syariah membeli barang yang diperlukan nasabah atas nama bank syariah tersebut sendiri, dan pembelian ini harus sah dan bebas riba.

5. Bank syariah harus menyampaikan semua hal yang berkaitan dengan pembelian, misalnya jika pembelian dilakukan secara utang. 
6. Bank syariah kemudian menjual barang tersebut kepada nasabah (pemesan) dengan harga jual senilai harga beli plus keuntungannya. Dalam kaitan ini bank syariah harus memberitahu secara jujur harga pokok (modal) barang kepada nasabah berikut biaya yang diperlukan.

7. Penjual (bank syariah) harus menjelaskan kepada pembeli (nasabah) bila terjadi cacat/kerusakan atas barang sesudah pembelian.

8. Nasabah membayar harga barang yang telah disepakati tersebut pada jangka waktu tertentu yang telah disepakati.

9. Untuk mencegah terjadinya penyelewengan, penyalahgunaan, atau kerusakan akad tersebut, pihak bank dapat mengadakan perjanjian khusus dengan nasabah misalnya untuk meminta jaminan.

10. Jika Bank syariah hendak mewakilkan kepada nasabah untuk membeli barang dari pihak ketiga, akad jual beli murabahah harus dilakukan setelah barang, secara prinsip, menjadi milik bank syariah tersebut.

\section{METODOLOGI PENELITIAN}

\section{a. Jenis Penelitian}

Jenis penelitian yang dilakukan menggunakan penelitian kualitatif berbasis pendekatan deksriptif. Penelitian kualitatif ini bertujuan untuk menganalisa aplikasi akad Musyarakah Mutanaqisah (MMQ) dan Murabahah. Penelitian ini bersumber dari studi kasus yang menghasilkan input data kualitatif dengan bantuan observasi/wawancara, kemudian data tersebut diolah menggunakan analisis SWOT.

\section{b. Sumber Data}

Sumber data terdiri dari dua sumber, yaitu :

1. Data Primer

Data ini diperoleh melalui wawancara langsung dengan Bapak Indra Darmawan sebagai Head Of Relationship Manager SME Bank Muamalat Indonesia, dan wawancara terstruktur dengan Bapak Indra Darmawan sebagai Relationship Manager SME, Nadzira Qalbi sebagai 
Muamalat Officer Development

Program (MODP), Bapak Aldi

dan Ibu Nadhira sebagai nasabah

KPR iB Muamalat.

2. Data Sekunder

Data ini diperoleh melalui studi

dokumentasi terhadap laporan

keuangan Bank Muamalat tahun 2018, panduan produk KPR Ib Muamalat Kongsi no. 01/RPDD/PMBY/2010, PBI No. 9/19/PBI/2007 tentang

Murabahah, dan referensi terkait.

\section{c. Teknik Pengumpulan Data}

Teknik yang digunakan dalam penelitian ini adalah :

1. Riset Kepustakaan

Riset ini di maksudkan untuk mendapatkan acuan teori dalam melengkapi data yang ada. Dengan cara membaca buku-buku, mempelajarai literatur dan catatan yang berhubungan dengan akad pembiayaan Murabahah, agar apa yang didapatkan benar-benar memiliki landasan teori dan acuan yang jelas.

2. Riset Lapangan

Ini dimaksudkan untuk mendapatkan data primer penelitian sebagai tekhnik pengumpulan data utama dalam hasil penelitian, yaitu dengan melakukan :

a. Observasi

b. Wawancara

c. Dokumentasi

\section{d. Teknik Analisis Data}

Metode analisis yang digunaka dalam penelitian ini adalah mengunakan konsep Miles dan Huberman. Dalam konsep Miles dan Huberman (1984), dikutip oleh Sugiyono (2012), dikemukakan bahwa tiga aktivitas analisis data. Aktivitas pertama yaitu

1. Data reduction, sebuah aktivitas menerangkan sehingga memudahkan pengumpulan data,

2. Data display, sebuah aktivitas menyajikan data agar terorganisasikan dan mudah dipahami.

3. Conclusion drawing / verivication, sebuah aktivitas penarikan kesimpulan dan verifikasi berdasarkan buktibukti data yang telah dikumpulkan. 


\section{HASIL DAN PEMBAHASAN}

\section{a. Aplikasi Pembiayaan}

\section{Murabahah Pada Bank}

\section{Muamalat Indonesia}

Murabahah yaitu akad jual beli yang dilakukan pihak bank dengan nasabah dengan ketentuan margin yang diberikan pihak bank sudah ditentukan diawal akad. Sehingga nasabah sudah mengetahui berapa besar angsuran yang harus dibayarkan kepada bank hingga akhir masa pembiayaan selesai. Dalam aplikasinya akad Murabahah biasa digunakan pada properti jadi, properti baru (non Indent), properti indent, renovasi, konstruksi, serta penjaminan properti.

Pada akad Murabahah, pihak bank menerbitkan rekening atas nama nasabah, kemudian bank muamalat membelikan properti atas nama nasabah, yang di wakilkan kepada nasabah. Dalam hal ini nasabah mendapatkan dana secara cash yang diberikan pihak bank, kemudian nasabah memberikan dana tersebut kepada pihak penjual/developer. Atau biasa disebut dengan Murabahah dengan Wakalah.

Pada prosesnya nasabah juga tidak diharuskan memilih penjual properti yang sudah bekerjasama dengan bank muamalat, tetapi bisa memilih properti yang diinginkan. Kecuali pada pembelian properti indent. Pada proses ini pihak developer harus bekerjasama terlebih dahulu dengan bank muamalat. karena pada properti indent biasanya masih harus dilakukan pemecahan sertifikat, sehingga pihak bank bisa mengontrol proses tersebut kepada pihak developer. Hal tersebut sulit dilakukan jika pihak developer belum bekerjasama dengan pihak bank.

Jika pada proses perjalanan pembiayan nasabah ingin melunasi sebelum jatuh tempo maka akad ini sangat menguntungkan, karena pihak bank bisa memberikan diskon yang cukup besar kepada nasabah. Tetapi jika terjadi Non Performing Financing (NPF) pada proses ini, maka pihak bank cukup berisiko karena kepemilikan properti sudah berpindah tangan di awal akad kepada nasabah.

Akad murabahah merupakan akad yang selalu tawarkan oleh pihak bank muamalat jika ada nasabah yang ingin mengajukan KPR. Keuntungan dari akad ini adalah angsuran sudah ditetapkan diawal sehingga nasabah sudah bisa mengetahui berapa besar angsuran yang harus dibayarkan hingga 
akhir masa pembiayaan. Ini juga yang membuat nasabah banyak memilih akad ini dibanding akad MMQ. Sekitar 80\% dari akad KPR iB muamalat yang digunakan, menggunakan akad Murabahah. Dan juga akad ini lebih familiar bagi nasabah dibanding akad MMQ. Pada umumnya nasabah datang menggunakan KPR bank syariah karena mereka mnginginkan angsuran yang sudah bisa di kalkulasi di awal akad, sehingga akad murabahah sangat cocok dengan kebutuhan tersebut. Tentu pada prosesnya bukan berarti akad ini menetapkan angsuran tetap dari tahun pertama hingga akhir, tetap ada perubahan angsuran, tetapi angsuran tersebut juga sudah dikalkulasikan oleh pihak bank, sehingga angsuran tersebut juga telah disepakati oleh nasabah pada awal perjanjian akad.

Untuk properti indent bank muamalat juga menggunakan akad ini, hal ini membuat stigma bahwa akad murabahah pada KPR iB muamalat menjadi akad KPR yang multi guna. Padahal akad ini tidak bisa mencakup pembelian pembiayaan properti yang barangnya belum terlihat. Pihak bank muamalat seakan belum memperluas potensi akad yang harusnya digunakan untuk proses ini. sebenarnya pihak bank muamalat sudah menggunakan akad Ijarah Maushufah fii Dzimma (IMFD) pada pembiayaanya, tetapi karena berbagai kendala akad tersebut belum digunakan pada KPR iB muamalat. sehingga akad yang digunakan masih menggunakan akad murabahah.

Berikut skema pembiayaan murabahah dengan wakalah pada Bank Muamalat Indonesia :

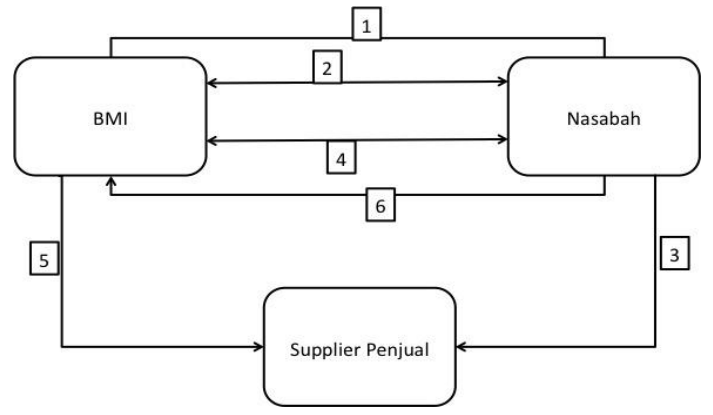

sumber: Hasil Olahan Penulis

\section{Keterangan :}

1. Nasabah mengajukan permohonan untuk membeli barang kepada bank. Bank memberikan persuyaratan atas pengajuan nasabah, serta dilakukan negoisasi harga

2. Bank memberikan offering letter kepada nasabah dan wakalah untuk pembelian barang. Tujuan dari pemberian wakalah ini adalah agar nasabah dapat 
melakukan transaksi di awal pembelian barang dengan penjual secara tidak tunai

3. Nasabah membeli barang dari supplier/penjual berdasarkan akad wakalah (pembelian nasabah dilakukan secara tidak tunai)

4. Bank dan nasabah melakukan akad jual beli (murabahah) atas barang yang telah dibeli

5. Nasabah melakukan pembayaran kepada bank secara angsuran (margin dan pokok).

Berikut Pembiayaan KPR Indent menggunakan akad murabahah pada Bank Muamalat Indonesia :

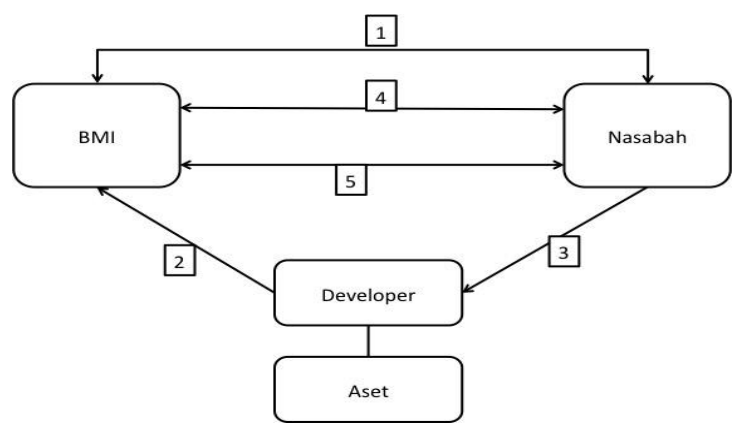

Sumber : Hasil olahan penulis

Keterangan :

1. Nasabah mengajuka permohonan pembelian asset kepada bank, bank memberikan syarat agar developer harus yang sudah bekerjasama dengan pihak BMI
2. Developer perumahan harus sudah bekerjasama dengan pihak BMI, sehingga pihak BMI dan developer yang akan mengurusi surat dll serta mencairkan dananya langsung kepada developer sesuai harga

3. Nasabah bisa melihat aset melalui pihak developer

4. BMI dan nasabah melakukan akad murabahah terhadap aset yang sudah dibeli

5. Nasabah melakukan pembayaran kepada BMI secara angsuran (margin dan Pokok)

\section{b. Analisis SWOT Pada Akad Murabahah}

a. Srategi Kekuatan dan Peluang $(\mathrm{S}+\mathrm{O})$

Strategi keterkaitan kekuatan dan peluang harus memiliki beberapa faktor yang ada sehingga strategi tersebut dapat dijadian pengembangan murabahah oleh Bank Muamalat Indonesia. Pertama, kekuatan murahabah dalah dapat diterapkan pada produk pembiayaan Pemilikian rumah (KPR) indent syariah berkaitan dengan 2 (dua) peluang, yaitu: Akad Murabahah bisa digunakan untuk berbagai akad Pembiayaan properti dan Perkembangan investasi properti di 
Indonesia. Kekuatan dan peluang tersebut dapat menjadi strategi pengembangan akad murabahah untuk pembiayaan properti dan mendorong perkembangan investasi properti di Indonesia.

Kedua, kekuatan yang dmiliki oleh murabahah adalah legalitas hukum terjamin. Kekuatan yang dimiliki murabahah tersebut berkaitan dengan peluang, yaitu: perkembangan investasi properti di Indonesia, dan meningkatnya pertumbuhan KPR syariah. Kekuatan dan peluang tersebut dapat menjadi suatu strategi untuk penetapan aturan akad murabahah untuk mengatur pembiayaann investasi properti dan KPR syariah.

Ketiga, kekuatan yang dimiliki oleh murabahah adalah menjadi akad yang familiar dibandingkan dengan akad-akad yang lain. Kekuatan ini berkaitan dengan peluang, yaitu: akad Murabahah bisa digunakan untuk berbagai akad Pembiayaan properti dan murabahah menjadi solusi pada pembiayaan Properti. Kekuatan dan peluang tersebut dapat menjadi suatu strategi, di mana Bank Muamalat Indonesia membuat program pendukung pelaksanaan akad murabahah sebagai solusi pembiayan properti.

Keempat, kekuatan yang dimiliki oleh murabahah adalah objek Murabahah, boleh diakadkan meskipun penjual belum memiliki barang. Kekuatan tersebut berkaitan dengan peluang, yaitu: perkembangan investasi properti di Indonesia dan meningkatnya pertumbuhan KPR syariah. Kekuatan dan peluang tersebut dapat menjadi strategi, di mana Bank Muamalat Indomesia mengembangkan fasilitas pembayaran murabahah untuk mendukung perkembangan investasi properti dan pertumbuhan KPR syariah.

Lima, kekuatan yang dimiliki oleh murabahah adalah menjadi solusi ketika pembiayaan proyek yang membutuhkan dana sangat besar dan modal bank syariah yang terbatas. Kekuatan tersebut berkaitan dengan peluang, yaitu: perkembangan investasi properti di Indonesia dan meningkatnya pertumbuhan KPR syariah. Kekuatan dan peluang tersebut dapat dijadikan sebagai strategi untuk pengembangan fasilitas pembayaran investasi properti dan KPR.

Kesimpulan dari faktor kekuatan dan peluang adalah pengembangan akad 
murabahah untuk pembiayaan properti dan mendorong perkembangan investasi properti di Indonesia, penetapan aturan akad murabahah untuk mengatur pembiayaann investasi properti dan KPR syariah, membuat program pendukung pelaksanaan akad murabahah sebagai solusi pembiayan properti, mengembangkan fasilitas pembayaran murobahah untuk mendukung perkembangan investasi properti dan pertumbuhan KPR syariah, dan pengembangan fasilitas pembayaran investasi properti dan KPR.

b. Strategi Kelemahan dan Peluang $(\mathrm{W}+\mathrm{O})$

Strategi keterkaitan antara kelemahan dan peluang harus melihat beberapa fakor yang ada serta merumuskan peluang untuk mengatasi kelemahan pada murabahah. Pertama, kelemahan yang dimiliki murabahah adalah transaksi (akad) dalam Murabahah digunakan untuk berbagai keperluan pembiayaan property nasabah. Kelemahan ini dapat diatasi dengan peluang, yaitu: akad Murabahah bisa digunakan untuk berbagai akad Pembiayaan properti, murabahah menjadi solusi pada pembiayaan Properti, dan perkembangan investasi properti di Indonesia. Untuk mengatasi kelemahan tersebut adalah dengan menetapkan peraturan untuk mengatur akad murabahah untuk menjadi solusi pembiayaan properti dan mendukung perkembangan investasi properti.

Kedua, kelemahan yang dimiliki oleh murabahah adalah sangat rentan terhadap kredit macet. Kelemahan yang dimiliki murabahah berkaitan dengan peluang, yaitu: perkembangan investasi properti di Indonesia dan meningkatnya pertumbuhan KPR syariah. Keterkaitan tersebut dapat menjadi suatu strategi yaitu melakukan kerjasama dengan instansi terkait untuk menjaga keberlangsungan perkembangan properti dan pertumbuhan KPR syariah.

Ketiga, kelemahan yang dimiliki oleh murabahah adalah kurangnya pemahaman nasabah tentang konsep murabahah. Kelemahan tersebut berkaitan dengan peluang, yaitu: digunakan untuk berbagai akad Pembiayaan properti dan murabahah menjadi solusi pada pembiayaan Properti. Strategi yang dapat diterapkan untuk mengatasi kelemahan ini adalah melakukan sosialisasi dan publikasi tentang akad murabahah sebagai akad 
untuk pembiayaan properti dan solusinya.

Kesimpulan dari faktor kelemahan dan peluang ini adalah menetapkan peraturan untuk mengatur akad murabahah untuk menjadi solusi pembiayaan properti dan mendukung perkembangan investasi properti, melakukan kerjasama dengan instansi terkait untuk menjaga keberlangsungan perkembangan properti dan pertumbuhan KPR syariah, dan melakukan sosialisasi dan publikasi tentang akad murabahah sebagai akad untuk pembiayaan properti dan solusinya.

c. Strategi Kekuatan dan Ancaman $(\mathrm{S}+\mathrm{T})$

Strategi keterkaitan antara kekuatan dan ancaman harus melihat faktor-faktor yang bertujuan meredam ancaman dengan memakai kekuatan yang ada. Pertama, kekuatan yang dimiliki oleh murabahah adalah dapat diterapkan pada produk Pembiayaan Pemilikan Rumah (PPR) indent syariah dan menjadi akad yang cukup familiar di banding akad-akad lainnya. Kekuatan yang dimiliki dapat mengatasi ancaman, yaitu: nasabah tidak membayar cicilan dengan sengaja dan nasabah berhenti membayar angsuran. Strategi yang dapat diterapkan untuk mengatasi ancaman adalah dengan kekuatan adalah melakukan pengawasan dalam pelaksaaan akad murabahah.

Kedua, kekuatan yang dimiliki oleh murabahah adalah murabahah dapat diterapkan pada produk Pembiayaan Pemilikan Rumah (PPR) indent syariah, dan menjadi solusi ketika pembiayaan proyek yang membutuhkan dana sangat besar dan modal bank syariah yang terbatas. Ancaman yang dapat diatasi dengan 2 kekuatan tersebut adalah terjadi pemindahan kepemilikan diawal akad. Ancaman tersebut dapat diatasi dengan kekuatan melalui strategi menetapkan peraturan yang mengatur pemindahan kepemilikan diawal akad untuk properti indent dan proyek dengan dana besar.

Kesimpulan dari faktor kekuatan dan kelemahan adalah kekuatan adalah melakukan pengawasan dalam pelaksaaan akad murabahah dan menetapkan peraturan yang mengatur pemindahan kepemilikan diawal akad untuk properti indent dan proyek dengan dana besar.

d. Strategi Kelemahan dan Ancaman $(\mathrm{W}+\mathrm{T})$

Strategi keterkaitan kelemahan dan ancaman harus melihat dari faktor- 
faktor, di mana kelemahan ancaman tersebut dapat di kontrol untuk mengurangi dampak negatif yang berimbas pada penerapan akad murabahah. Pertama, kelemahan yang dimiliki oleh murabahah adalah transaksi (akad) dalam Murabahah digunakan untuk berbagai keperluan pembiayaan properti Nasabah.

Keterkaitan kelemaan tersebut dengan ancaman berupa Transaksi (akad) dalam Murabahah digunakan untuk berbagai keperluan pembiayaan properti nasabah dan nasabah berhenti membayar angsuran. Kelemahan dengan ancaman tersebut sangat berhubungan karena bebasnya penggunaan akad murabahah dapat menyebabkan cicilan tidak dibayar dengan sengaja dan berhentinya pembayaran angsuran nasabah. Strategi yang tepat adalah melakukan pengawasan dalam pelaksaanan akad murabahah.

Kedua, kelemahan yang dimiliki oleh murabahah adalah sangat rentan terhadap kredit macet. Ancaman yang dimiliki oleh murabahah adalah Nasabah tidak membayar cicilan dengan sengaja dan nasabah berhenti membayar angsuran. Strategi yang tepat untuk mengatasi ancaman tersebut adalah dengan peningkatan kinerja lembaga seperti badan pengawasan serta melakukan kerjasama dengan pihak berwajib.

Ketiga, kelemahan yang
dimiliki oleh murabahah adalah
kurangnya pemahaman nasabah tentang
konsep murabahah. Ancaman yang
dimiliki oleh murabahah adalah nasabah
tidak membayar cicilan dengan sengaja,
terjadi pemindahan kepemilikan diawal
akad, dan nasabah berhenti membayar
angsuran. Strategi yang tepat untuk
mengatasi ancaman tersebut adalah
melakukan komunikasi intentasif untuk
meningkatkan pemahaman nasabah.

\section{KESIMPULAN}

1. Faktor kekuatan dan peluang Murabahah adalah pengembangan akad untuk pembiayaan properti dan mendorong perkembangan investasi properti di Indonesia, penetapan aturan akad murabahah untuk mengatur pembiayaann investasi properti dan KPR syariah, membuat program pendukung pelaksanaan akad murabahah sebagai solusi pembiayan properti,mengembangkan fasilitas pembayaran meubahah untuk mendukung perkembangan 
investasi properti dan pertumbuhan KPR syariah, dan pengembangan fasilitas pembayaran investasi properti dan KPR.

2. Dari faktor kelemahan dan peluang ini adalah menetapkan peraturan untuk mengatur akad murabahah untuk menjadi solusi pembiayaan properti dan mendukung perkembangan investasi properti, melakukan kerjasama dengan instansi terkait untuk menjaga keberlangsungan perkembangan properti dan pertumbuhan KPR syariah, dan melakukan sosialisasi dan publikasi tentang akad murabahah sebagai akad untuk pembiayaan properti dan solusinya.

3. Dari faktor kekuatan dan kelemahan adalah kekuatan adalah melakukan pengawasan dalam pelaksaaan akad murabahah dan menetapkan peraturan yang mengatur pemindahan kepemilikan diawal akad untuk properti indent dan proyek dengan dana besar.

\section{DAFTAR PUSTAKA}

Abdul Ghofur Anshori, Hukum

Perjanjian Islam Di Indonesia (Konsep, Regulasi, dan Implementasi),
Yogyakarta: Gadjah Mada University

Press, 2010.

Adiwarman A. Karim, Bank Islam

Analisis Fiqih dan Keuangan, Jakarta:

PT RajaGrafindo Persada, 2017

Antonio, Muhammad Syafi'i, Bank

Syariah : Dari Teori ke Praktek, Jakarta:

Gema Insani, 2017

Dwi suwiknyo, Jasa jasa Perbankan

Syariah, Yogyakarta: PT Pustaka

Pelajar, 2010

Fajar Nur'aini DF, Teknik Analisis

SWOT, Yogyakarta: Quadrant, 2016

Ikatan Bankir Indonesia, Memahami

Bisnis Bank Syariah, Jakarta: PT

Gramedia Pustaka Utama, 2018

Ikatan Bankir Indonesia, Mengelola

Bank Syariah, Jakarta: PT Gramedia

Pustaka Utama, 2018

Ikatan Bankir Indonesia, Mengelola

Bisnis Pembiayaan Bank Syariah, Jakarta: PT Gramedia Pustaka Utama, 2015 
Ismail Nawawi, Fikih Muamalah Klasik

dan Kontemporer, Bogor : Ghalia

Indonesia, 2012

Muhammad Ridwan Basalamah dan

Mohammad Rizal, Perbankan Syariah,

Malang: Empatdua Media, 2018

Muhammad Syafi'i Antonio, Bank

Syariah : Dari Teori ke Praktek, Jakarta:

Gema Insani, 2017

Syed Nawab Haider Naqvi, Menggagas

Ilmu Ekonomi Islam, Yogyakarta:

Pustaka Pelajar, 2009

Widodo, Metodologi Penelitian Populer

\& Praktis, Jakarta: PT Rajagrafindo

Utama, 2019

Qaradhawi, Yusuf, Halal dan Haram, Bandung: Penerbit Jabal, 2014

Tarmizi, Erwandi, Muamalat Kontemporer, Bogor: Berkat Mulia Insani, 2017

Wardiyah, Mia Lasmi, Pengantar Perbankan Syariah, Bandung: Pustaka Setia, 2019
Widodo, Metodologi Penelitian Populer \& Praktis, Jakarta: PT Rajagrafindo Utama, 2019 